\title{
Control of stray dog population by single intratesticular injection of tannic acid
}

\author{
I.A. Zedan and M.S. Al-Badrany \\ Department of Surgery and Theriogenology, College of Veterinary Medicine, University of Mosul, Mosul, Iraq
}

\begin{tabular}{l} 
Article information \\
\hline Article history: \\
Received June 09, 2021 \\
Accepted June 30, 2021 \\
Available online November 27, 2021 \\
\hline Keywords: \\
Chemical castration \\
Tannic acid \\
Dog \\
\\
\hline Correspondence: \\
M.S. Al-Badrany \\
muneert16@yahoo.com
\end{tabular}

Article information

history:

Available online November 27, 202

\begin{abstract}
The present study was aimed to perform the alternative technique of chemical castration for controlling the increasing population of stray dogs. Eight adult male dogs were used in the current study. The dogs were Experimentally divided randomly into two groups. The first group included four dogs that were injected intratesticular with tannic acid while the second group which includes four dogs were injected intratesticular with normal saline and considered as a control group. The clinical examination, hormonal assay, and histopathological changes were detected. The result of the current study shown testicular tissue swelling in both treated and control groups this swelling subsided gradually within 48 hours, but without any serious complications. There were no significant changes in testosterone levels in both the control and treated groups. The histopathological results of the treated group after 30 days post-surgery showed focal necrosis and desquamation of germinal cells and Sertoli cells. We can conclude that chemical neutralization is a simple technique, can be used for controlling the increasing population of stray dogs.
\end{abstract}

DOI: 10.33899/ijvs.2021.130454.1826, (CAuthors, 2021, College of Veterinary Medicine, University of Mosul.

This is an open access article under the CC BY 4.0 license (http://creativecommons.org/licenses/by/4.0/).

\section{Introduction}

There are two techniques for dog castration known as, the surgical and chemical methods. The surgical technique required professional veterinarian as well as postoperative care, while the non- surgical method chemical sterilization by injection of some chemicals in the testes parenchyma (1). The chemical neutralization commonly performed in the rabbits, rats, goats, and dogs by intratesticular injection of chemical materials as glycerol (2) formalin (3) calcium chloride $(4,5)$ tannic acid, lactic acid $(1,6)$ zinc solution $(7,8)$ and sodium chloride $(9)$. This method has been used to overcome the ever-increasing number of stray dogs, which considered as global trouble with significant public health (10). Especially in Iraq, where the method of euthanasia is useless and may not bear a human nature, so many researches in many countries were suggested many kinds of chemical neutralization to solve this trouble (11). The castration of the male dogs provided behavioral and health benefits as well as helping in pet population control, it can help to prevent some undesirable behaviors such as urine splashing or scent marking in house, mounting other dogs, aggression toward other male dogs, and roaming $(12,13)$.

The objective of the current study is to evaluate the effect of intratesticular injection of tannic acid to induce permanent sterility in male dogs.

\section{Materials and methods}

Twelve adult male dogs of the local breed were used in this study. The age and weight of the dogs were about 2-5 years, $12-20 \mathrm{~kg}$, respectively. All dogs were housed in the animal house of the College of Veterinary Medicine under the same conditions of feeding and housing. Dogs were randomly divided into two groups. In the first group, four dogs were used, the tannic acid was injected at a dose of $200 \mathrm{mg}$ (prepared by dissolving $400 \mathrm{mg}$ of tannic acid in distilled water in a volume of $2 \mathrm{ml}$ at the time of injection) for each testicle inside the testis, while in the second group, 
four dogs were injected with a normal saline solution of the same size in the first group and this group was considered as a control group. The site of the operation in the perineum and scrotum area was routinely prepared for aseptic deep injection into the testis (14). The needle was inserted into the central part of the testicle next to the epididymis. The injection technique was performed as the same in the two groups deeply through the tissue towards the center of the testes. The daily clinical examination was performed on the animals of the two groups, while the hormonal examination was carried out on the $15^{\text {th }}$ and $30^{\text {th }}$ days after the injection, by collect blood from all dogs for both groups. The blood was expelled to obtain the serum, where the ELISA method was used. The surgical castration was don after 30 days from injection (15), samples was obtained for histopathological preparation and sectioning $(16,17)$.

\section{Results}

The results of the current study exhibited signs of local pain and discomfort, restlessness there were changes in behavior during the first 48 hours, loss of appetite changes in temperament these signs gradually subsided and the animals become more docile during the first few days after treatment. Unlike the first group the control group exhibited fewer changes in behaviors and temperament. Clinically there was swelling, edema at scrotal and perineum region which subsided gradually during few days post-surgery, these inflammatory signs do not affect animals. The results of hormonal assessment exhibited no significant changes in all operative and control animals (Table 1). The results of the gross examination at 30 days post-treatment showed atrophied, hard consistency testis with focal necrotized lesion (Figure 1). The testis was adherent firmly with the tunica vaginalis. Unlike in fist group there was no pathological changes evidence in the control group, the testis appeared normally.

Table 1: Testosterone level of dogs $\mathrm{mg} / \mathrm{kg}$

\begin{tabular}{lccc}
\hline no. & Pre injection & After 15 days & After 30 day \\
\hline 1 & $0,73 \mathrm{a}$ & $1,76 \mathrm{a}$ & $1,52 \mathrm{a}$ \\
2 & $0,96 \mathrm{a}$ & $1,95 \mathrm{a}$ & $1,74 \mathrm{a}$ \\
3 & $0,64 \mathrm{a}$ & $0,69 \mathrm{a}$ & $0,60 \mathrm{a}$ \\
4 & $0,05 \mathrm{a}$ & $0,05 \mathrm{a}$ & $0,05 \mathrm{a}$ \\
5 & $0,82 \mathrm{a}$ & $0,76 \mathrm{a}$ & $0,94 \mathrm{a}$ \\
6 & $0,80 \mathrm{a}$ & $0,74 \mathrm{a}$ & $0,92 \mathrm{a}$ \\
7 & $0,67 \mathrm{a}$ & $0,80 \mathrm{a}$ & $0,60 \mathrm{a}$ \\
8 & $0,95 \mathrm{a}$ & $1,05 \mathrm{a}$ & $1,60 \mathrm{a}$ \\
\hline
\end{tabular}

The histopathological changes of testes after 30 days of injection of tannic acid showed disappearance of normal architectural of testicular tissue, the seminiferous tubules disappearance of basement membranes in some of the tubules with spermatogenic arrest of primary and secondary spermatogonia and atrophy of Sertoli cells, the lumen of tubules was empty from spermatids while other sections showed occlusion of the lumen tubules by hyaline cast (Figures 2 and 3). Other sections showed highly infiltration of mononuclear inflammatory cells in the interstitial space as (Figure 3) some of seminiferous tubules appear normal in another section (Figure 4). Unlike the first group, the control group exhibited no changes in size and architecture of the organ no histological changes are evidence (Figure 5). Many attempts for semen collection by masturbation was failed. The epididymal sperm count reveled oligospermia.

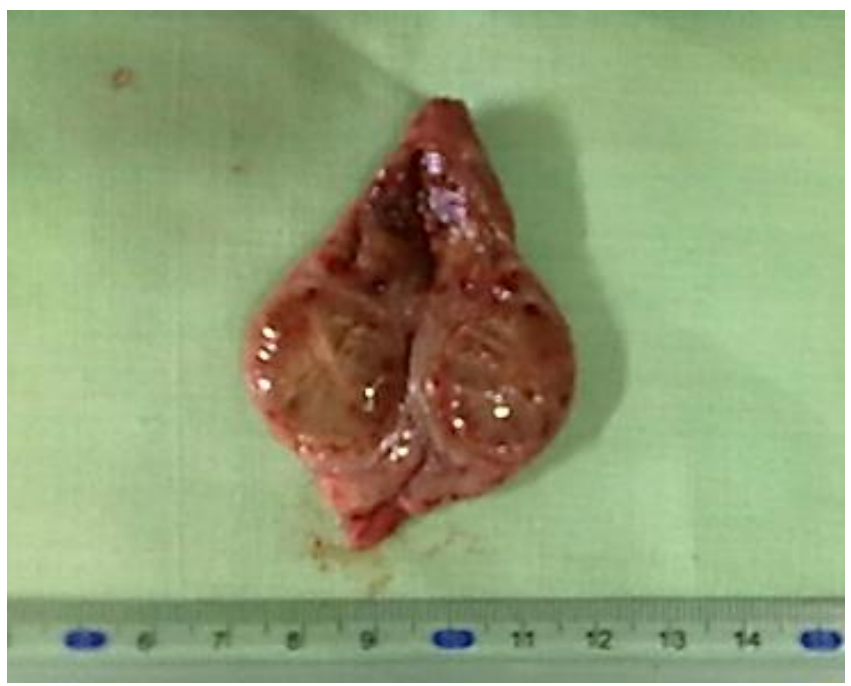

Figure 1: Image of treated testes of dog 30 days of intratesticular injection manifested by signs of atrophy and necrosis.

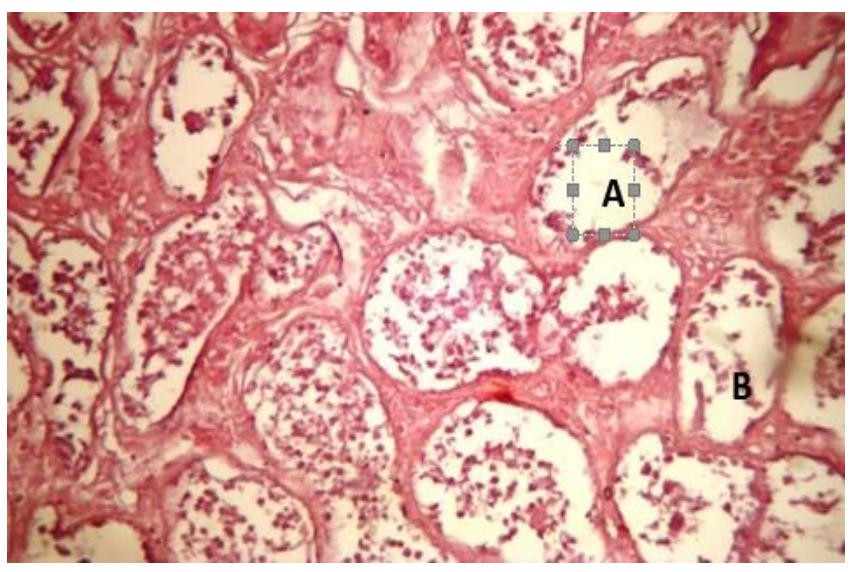

Figure 2: Testis section (A) disappear of basement membranes (B) seminiferous tubules disappear of primary and secondary spermatogonia absence of Sertoli cell. H\&E, X90. 
Iraqi Journal of Veterinary Sciences, Vol. 35, Supplement II, 2021 (33-36)

Proceedings of the 3rd National (1 st International) Conference of Biology, College of Education for Pure Science, University of Mosul

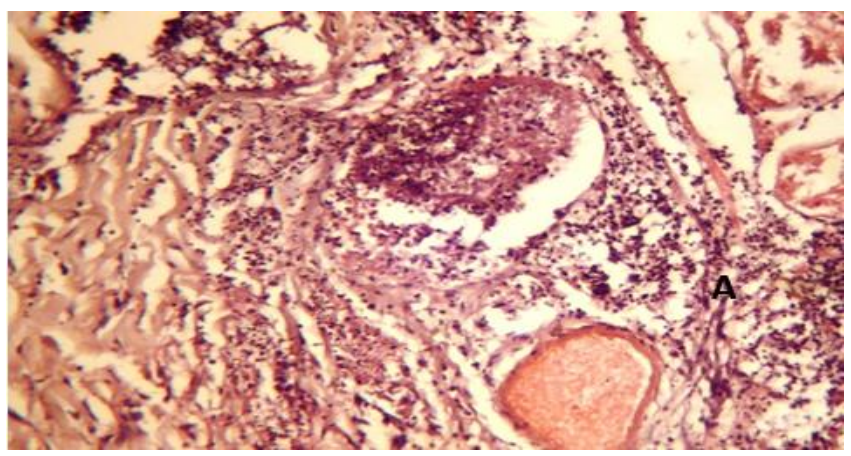

Figure 3: Dog testis after 30 days of $200 \mathrm{mg}$ tannic acid injected intratesticular, (A) infiltration of mononuclear inflammatory cells. H\&E, X90.

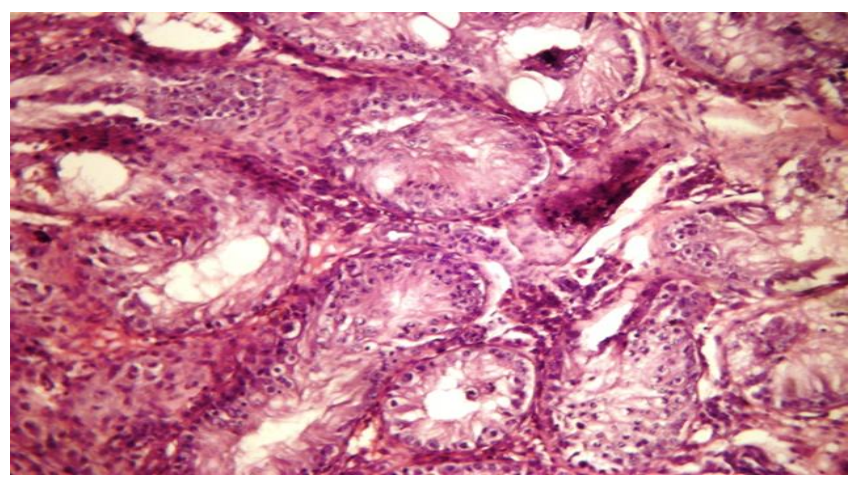

Figure 4: Dog testis after 30 days of $200 \mathrm{mg}$ tannic acid injected intratesticular, seminiferous tubules appear normal. $\mathrm{H} \& \mathrm{E}, \mathrm{X} 90$.

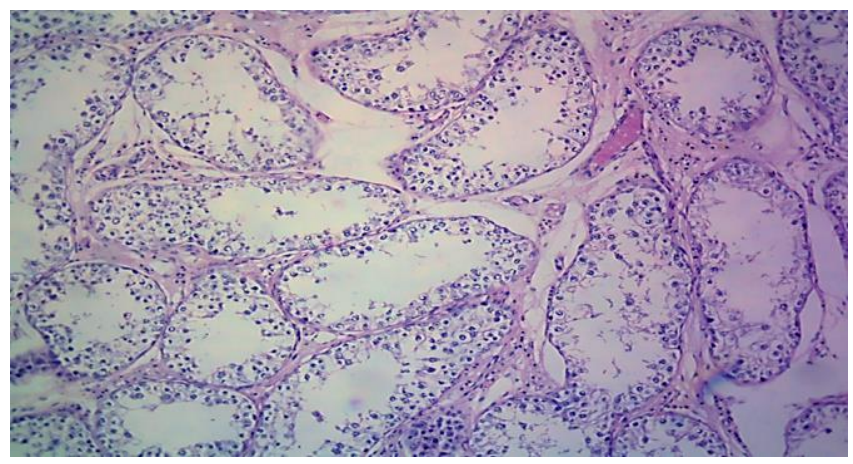

Figure 5: Normal testicular tissue of control group normal architecture. H\&E, X90.

\section{Discussion}

Many researchers are continuously making their effort for reaching to the best method for neutralization. for this reason, our research has been done. The signs of pain, restlessness, discomfort, scrotal and perineal edema which exhibited which occurs in group 2 this mainly due to the local inflammatory reaction due to reaction of tannic acid and these signs subsided within the first few days posttreatment this also may due to reversible testicular tissue damage (13). Grossly the atrophied testis, signs of local necrosis, hard consistency and paleness in color with adhesion testis with the tunica vaginalis these signs agree with Mohammad et al. (3) Chatterjec et al. (4) and Fahim et al. (7), whom explain that the tannic acid bound with protein and this lead to composing complex compound. The results of hormonal assay exhibited no significant changes in the testosterone level between pro and post-injection this considers with, Chatterjec et al. (4), Fahim et al. (7), AlObaddy and Al-Badrany (1), who found that the castration did not affect testosterone level. The testis adherent to the tunica vaginalis may due to deep introducing needle to the center of injection interstitial tissue this consider with Fordyce et al. (6).

The distraction of tubular system of testes that stops the trance port of semen due to severe histological changes in the organ tissue and this action is the same in Al-Obaddy and Al-Badrany (1), Mohammad et al. (3), Jana et al. (5). All the attempts for collection the semen was failed in the treated group, there was no inflammatory of histopathological or hormonal changes evidence in the control group this agree with Immegart (18), Threlfall and Singh (19). The histopathological changes in the first group exhibited general testicular degeneration with widespread tubular atrophy and a significant decrease of the testicular parenchyma. Seminiferous tubules were covered by one or two rows of cells with epithelial vacuolization. The basal membrane appeared with slightly reduced diameter and irregular profile. Sertoli cells appeared normal, while irreversible damage was due to the complete lack of spermatogonia and results in azoospermia. this finding was considered with Jana et al. (5) who noticed irreversible testicular damage and azoospermia.

\section{Conclusion}

In conclusion, we found that chemical castration by intratesticular injection of $200 \mathrm{mg}$ of a tannic acid good method for control overpopulation of dogs.

\section{Acknowledgement}

The authors would be thanks the College of Veterinary Medicine, University of Mosul for supporting this study.

\section{Conflict of interest}

Surgical castration need trained staff, post-operative care and time consuming opposite to chemical castration which alternative fast economic technique that enhance over population of stray dogs. 
Iraqi Journal of Veterinary Sciences, Vol. 35, Supplement II, 2021 (33-36)

Proceedings of the 3rd National (1 st International) Conference of Biology,

College of Education for Pure Science, University of Mosul

\section{References}

1. Al-Obaddy OS, Al-Badrany MS. Castration by chemical method and laparoscopy in equidae [master's thesis]. Mosul: College of Veterinary Medicine, University of Mosul, Mosul, Iraq; 2007.

2. Bakir B, Gulyuz F, Karaca F, Yuksel H, Sahin A, Uslu BA. Chemical castration in dogs. JHlth Sci. 2002;8:6-9. [available at]

3. Mohammad A,Awal MR, Sonkor KD, Nazmul HS, Masamichi K, Andriana B, Yoshihiro H. Formalin affects the male reproduction of black bengal goats during prepubertal stage even at low concentration: In vivo study. J Med Sci. 2004;4:84-89.DOI: $10.3923 / \mathrm{jms} .2004 .84 .89$

4. Chatterjec K, AliKM, De D,Mallick C,GhoshD. Induction of chemosterilization by single intratesticular calcium chloride injection in stray dogs. J AnimSci. 2009;4:22-29.DOI: 10.1016/j

5. JanaK, Samanta PK, GhoshD.Dose-dependent response to an intratesticular injection of calcium chloride for induction of chemosterilization in adult albino rats. Vet Res Commun. 2002;26(8):651-73. DOI: 10.1023/A:1020976905746

6. Fordyce G, Beaman NJ, Laing AR, Hodge PB, Campero C, Shepherd RK. An evaluation of calf castration by intra-testicular injection of a lactic acid solution. Aust Vet J. 1989;66(9):272-276. DOI: https:10.1111/j.1751-0813.1989.tb13950.x

7. Fahim MS, Wang M, Sutcu MF: Sterilization of dog with intraepididymal injection of zinc arginine. Contracept.1993;47:107-122. DOI: 10.1016/0010-7824(93)90113-L

8. TepsumethanonV, WildeH, Hemachudha T.Intratesticularinjection of a balanced zinc solution for permanent sterilization of dogs. J Med Assoc Thai. 2005;88(5): 686-9. [available at]

9. Canpolat I, Karabulut E, Eroksuz Y. Chemical castration of adult and non-adult male dogs with sodium chloride solution. J Agric Vet Sci. 2016;9(12):9-11. DOI: 10.9790/2380-0912010911

10. Singh BK. noninvasive therapeutic ultrasound sterilization in male dogs [PhD dissertation]. Jabalpur: NanajiDeshmukh Veterinary Science University, Jabalpur; 2008. 4-31 p.

11. Marston DA, McElhinney L, Taylor E. Quantifying and mapping the burden of human and animal rabies in Iraq. PLoSNegl Trop Dis. 2010;14(10):e0008622. DOI: 10.1371/journal.pntd.0008622

12. Julie KL. Non-surgical methods of sterilization: What's new. WSAVA. 2009;12(3): 1-10. [available at]

13. Okwee-AcaiJ, OjokL,Acon J. Testicularmorphologic and hormonal responses to an intratesticular injection of lactic acid for induction of chemosterilisation in adult mubende goats. African J Anim Biomed Sci. 2008;3:5-11. DOI: 10.1056/NEJM198105073041901

14. Slater D. Text book of small animal surgery. $3^{\text {rd }}$ ed. New York: Elsevier Press; 2003. 1527-1530 p.

15. Noakes DE,Parkinson TJ, England GCW. Arthur's veterinary reproduction and obstetrics. ${ }^{\text {th }}$ ed.China: Elsevier Ltd; 2001. 700-704 p.
16. Luna LG. Manual of histological staining methods of armed forces institute of pathology. $3^{\text {rd }}$ ed. New York: McGraw Hill Bock Com; 1968. 38-76 p.

17. Suvarna SK, LayutonC, Bancroft JD. Theory and practice of histological techniques. $7^{\text {th }}$ ed. New York: Churchill Livingstone Press; 2013. 12-32 p.

18. Immegart HM, Threlfall WR.Evaluation of intratesticular injection of glycerol for nonsurgical sterilization of dogs. Am J Vet Res. 2000;61(5):544-9. DOI: 10.2460/ajvr.2000.61.544

19. Leoci R, Aiudi G, Silvestre F, Lissner EA, Marino F, Lacalandra GM. Therapeutic ultrasound as a potential male dog contraceptive: Determination of the most effective application protocol. ReprodDomest Anim. 2015;50(5):712-8. DOI: 10.1111/rda.12548

$$
\begin{aligned}
& \text { السيطرة على عدد الكلاب الضالة عن طريق الحقن } \\
& \text { إبراهيم احمد زيدان و منير سالم البدراني }
\end{aligned}
$$

صممت التجربة الحالية لإيجاد طريقة بديلة للإخصاء و إمكانية

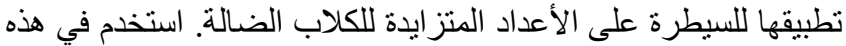

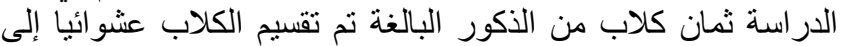
مجمو عتين. المجمو عة الأولى ضمت كن أربعة كلاب تم حقنها داخل منن

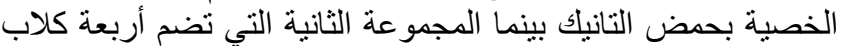

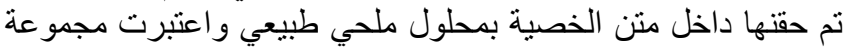

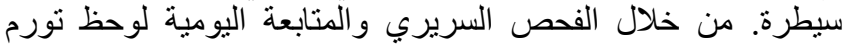

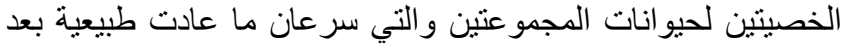

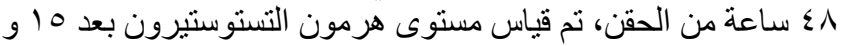

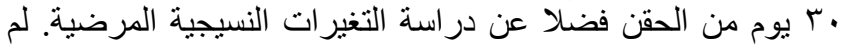
تكن هناك تغييرات كبيرة في مستويات هرمون التستوستيرون في كل في درن من مجموعة السيطرة والمعاملة. أظهرت النتائج النسيجية المرئية المرضية

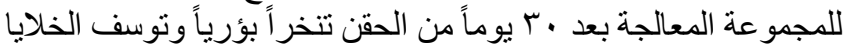
الجرثومية وخلايا سيرتولي. نستتنج هذه الدراسة إمكانية إنية استخدام حامض التنيك كطريقة سهلة للسيطرة على تز ايد الكلاب الضالة. 